International Journal of Poultry Science 5 (3): 241-246, 2006

ISSN 1682-8356

(C) Asian Network for Scientific Information, 2006

\title{
Body Fat of Broiler Chickens Fed Diets with Two Fat Sources and Conjugated Linoleic Acid
}

\author{
S.F. Zanini', G.L. Colnago ${ }^{2}$, B.M.S. Pessotti', M.R. Bastos ${ }^{1}$, F.P. Casagrande ${ }^{1}$ and V.R. Lima \\ 'Department of Veterinary Sciences, P.O. Box 16, CEP 29500-000, \\ Espirito Santo Federal University, Alegre (ES), Brazil \\ ${ }^{2}$ Department of Animal Sciences, Fluminense Federal University, Brazil
}

\begin{abstract}
The aim of this research was to evaluate the effect of CLA association with two vegetable oil sources on the body fat of broiler chickens. Broilers were distributed in a completely randomized factorial design $2 \times 5$ (two oil sources, i.e. soybean or canola oil and five levels of CLA supplementation, i.e. 0.0, 2.5, $5.0,7.5$ and $10.0 \mathrm{~g} / \mathrm{kg}$ ). For both sexes, supplementation with canola oil resulted in heavier birds $(P<0.05)$ when compared to soybean oil. The effect of CLA supplementation on final body weight of female birds was significant and explained by a linear response $(P<0.05)$. A linear reduction in abdominal fat pad content was observed on females receiving canola oil and CLA $(P<0.05)$. Canola oil fed male and female birds had a reduction in relative liver weight $(P<0.05)$ when compared to soybean oil fed birds. The supplementation of CLA resulted in lower relative liver weight in females birds fed canola oil when compared to that of females receiving soybean oil diets. Total serum cholesterol was lower $(P<0.05)$ in females fed canola oil when compared to that of females fed soybean oil. Birds fed soybean oil had a higher $(\mathrm{P}<0.05)$ fat liver content than those birds receiving canola oil. These results confirm the observation of heavier $(P<0.05)$ livers for birds receiving soybean oil in comparison with those receiving canola oil.
\end{abstract}

Key words: Broiler, conjugated linoleic acid, body fat

\section{Introduction}

During many years, the main objective of the poultry meat industry was to improve body weight and feed efficiency of the birds. However, in the modern poultry industry, there are other parameters that need to be taken into consideration such as low fat deposition on the body.

The supplementation of the broiler's diet with polyunsaturated fatty acids (PUFAs) reduced the hepatic lipogenesis (Clark, 1993). Recently several reports have shown that conjugated linoleic acid (CLA) has the potential to reduce fat deposition on the animal carcass (Ostrowska et al., 1999; Thiel-Cooper et al., 2001; Wiegand et al., 2002; Corino et al., 2002 and Akahoshi et al., 2003). This effect is related to changes in the genetic expression of lipogenic enzymes (Park et al., 1999; Bauman, 2001) such as the reduction of mRNA expression for the enzyme fatty acid synthetase, the esteraroil-CoA dessaturase and the acetyl-CoA carboxylase (Bauman, 2001), hinting that hepatic lipogenesis and fat deposition may be reduced by CLA supplementation. There are also reports of the CLA effect on the increased activity of the enzyme carnitine palmitoil-transferase (Pariza et al., 1997; Akahoshi et al., 2003) and hormone sensitive lipase (Pariza et al., 1997) and reduction in the activity of the acetyl-CoA carboxylase in the liver and fat tissue (Corino et al., 2002).

Therefore, since CLA and PUFAs have the potential to influence the lipid metabolism, it is believed that the use of CLA in association with different sources of fat in the diet may improve the productive efficiency as well as body fat deposition.

Much research has been carried out on the effects of dietary CLA supplementation on performance and lipid metabolism. However, there is not much information on the effect of the association of CLA with oil sources on the body fat of broiler chickens.

\section{Materials and Methods}

Two studies were conducted simultaneously using 100 male or 100 female Ross broiler chickens with 21 days of age at the start of the experiment. Ten birds per treatment were housed indoors, on floor pens and distributed in a completely randomized factorial design $2 \times 5$ (two oil sources, i.e. soybean or canola oil and five levels of CLA, i.e. 0.0, 2.5, 5.0, 7.5 and $10.0 \mathrm{~g} / \mathrm{kg}$ ). Oils used were supplied by Bünge Alimentos and CLA (LUTA® - CLA 60) by BASF. The source of CLA contained approximately $600 \mathrm{~g} / \mathrm{kg}$ conjugated isomers, as a $50: 50$ mixture of $18: 2$ cis- 9 , trans-11 and 18:2 trans-10, cis-12. The control diets had $40 \mathrm{~g} / \mathrm{kg}$ of soybean or canola oil. CLA supplementation levels were obtained by isometrically replacing soybean or canola oil in the control diets. From 1 to 21 days of age chicks were raised in a corn-soy diet with $210 \mathrm{~g} / \mathrm{kg}$ protein and 12.34 $\mathrm{MJ}$ of metabolizable energy per $\mathrm{kg}$ of diet. From 22 to 45 days of age the birds were fed the basal diet shown in Table 1. 
Zanini et al.: Effect of CLA association with two vegetable oil

Table 1: Ingredients and chemical composition of the basal diet

\begin{tabular}{lc}
\hline Ingredients & $\mathrm{g} / \mathrm{kg}$ \\
\hline Ground yellow maize & 610.90 \\
Soybean meal & 318.50 \\
Canola or soybean oil & 40.00 \\
Dicalcium phosphate & 10.50 \\
Limestone & 10.20 \\
Sodium chloride & 4.00 \\
Vitamin supplement ${ }^{1}$ & 2.50 \\
Mineral supplement & \\
Salinomycin, $12 \mathrm{~g} / 100 \mathrm{~g}$ & 0.70 \\
Dl- methionine & 0.50 \\
Zinc Bacitracin, $15 \mathrm{~g} / 100 \mathrm{~g}$ & 1.80 \\
Antioxidant $(\mathrm{BHT})$ & 0.30 \\
Calculated composition & 0.10 \\
Crude protein, $(\mathrm{g} / \mathrm{kg})$ & \\
Metabolizable energy, $\mathrm{MJ} / \mathrm{kg}$ & 190.00 \\
Analysed composition & 13.18 \\
Dry matter $(\mathrm{g} / \mathrm{kg})$ & \\
Crude protein, $(\mathrm{g} / \mathrm{kg})$ & 895.6 \\
\hline
\end{tabular}

Total fat, ( $\mathrm{g} / \mathrm{kg}$ ) 67,0 . ${ }^{1}$ Supply per $\mathrm{kg}$ of product the following vitamins and mineral: Vit. A, $15.000 .000 \mathrm{UI}$, Vit. $\mathrm{D}_{3}, 1.500 .000$ UI, Vit. E, 15.000 UI, Vit. $K_{3}, 3$ g, Vit. $B_{1}, 2$ g, Vit. $B_{2} 4$ g, Vit $B_{6}$, $3 \mathrm{~g}$, Vit $\mathrm{B}_{12}, 0,015 \mathrm{~g}$, niacin, $2 \mathrm{~g}$, pantothenic acid, $10 \mathrm{~g}$, folic acid, $1 \mathrm{~g}$, Choline, $250 \mathrm{~g}$, selenium, $100 \mathrm{mg}$ e and q.s.p., $1000 \mathrm{~g}$. ${ }^{2}$ Supply per $\mathrm{kg}$ of product the following minerals: $\mathrm{Fe}, 80$ g, $\mathrm{Cu}, 10 \mathrm{~g}, \mathrm{Co}, 2 \mathrm{~g}, \mathrm{Zn}, 50 \mathrm{~g}, \mathrm{Mn}, 60 \mathrm{~g}, \mathrm{l}, 1 \mathrm{~g}$ and q.s.p., $500 \mathrm{~g}$

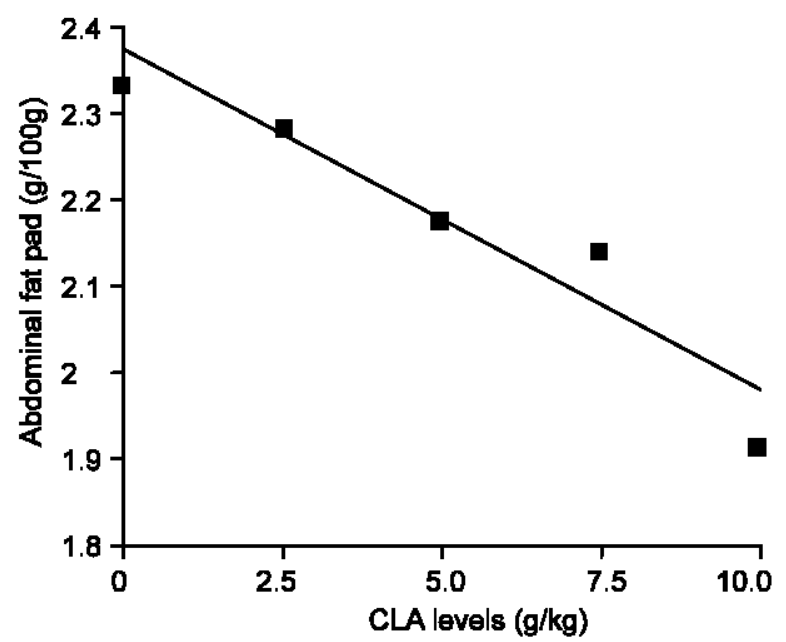

Fig. 1: Abdominal fat pad of female birds fed canola oil diets and supplemented with CLA $(\square-Y=2.36$ $\left.0.39 x, \quad R^{2}=0.90, \quad P<0.05\right)$. Each value is expressed as mean ( $n=5 /$ treatment)

The final body weight was determined individually at 45 days of age. Then, birds were killed by cutting the jugular vein and blood samples were collected from all 10 birds. Abdominal fat pads and livers were collected from the five birds with body weight closest to the mean body weight of the treatment. Total serum cholesterol was measured using spectrometry (LABTEST - cholesterol liquiform). The livers, gizzards and hearts of all birds were collected and kept under freezing conditions at $20^{\circ} \mathrm{C}$, until lipids were extracted using the technique of Folch et al. (1957).

The experimental data was subjected to analysis of variance using the System for Statistical and Genetic Analyses, developed by UFV (1997). Significant differences among means were determined by SNK test at $\mathrm{P}<0.05$ throughout this study. Regression analysis was used to report the effects of CLA levels. When there was an interaction $(P<0.05)$, the effect of the CLA level inside each oil source was determined according to Banzatto and Kronka (1992).

\section{Results}

The effect of oil source and of CLA supplementation on final body weight of chickens is shown in Table 2. For both sexes, supplementation with canola oil resulted in heavier birds $(P<0.05)$ when compared to soybean oil. The effect of CLA on final body weight of female birds was significant and explained by a linear response.

Abdominal fat pad content of females has shown a significant interaction between oil sources and CLA levels. A linear reduction in abdominal fat pad content was observed on females receiving canola oil and CLA $\left(Y=2.36-0.39 x, R^{2}=0.90\right.$, Fig. 1). Thus, the abdominal fat deposition was reduced from 2.33 to $1.91 \mathrm{~g} / 100 \mathrm{~g}$.

Table 3 shows the effect of oil source on relative liver weight $(P<0.05)$. Canola oil fed male and female birds had a reduction in liver weight $(P<0.05)$ when compared to soybean oil fed birds. An interaction between oil source and CLA was also observed on the relative liver weight in females birds $(\mathrm{P}<0.05)$. The supplementation of CLA produced lower relative of liver in females birds fed canola oil when compared to that of females receiving soybean oil diets $(P<0.05$, Table 3 ).

There was an effect of the oil source on the total serum cholesterol of females $(P<0.05)$. Total serum cholesterol was lower $(P<0.05)$ in females fed canola oil $(115.11$ $\mathrm{mg} / \mathrm{dL}$ ) when compared to that of females fed soybean oil $(131.76 \mathrm{mg} / \mathrm{dL})$. In both sexes, the supplementation with CLA in association with two oil sources influenced the serum cholesterol of birds $(P<0.05)$ and were explained by a quadratic effect (Fig. 2 and 3 ). Supplementation of the canola oil diet with $7.5 \mathrm{~g} / \mathrm{kg}$ of CLA resulted in a reduction on the concentration of serum cholesterol of male and female birds when compared to the soybean oil fed birds $(P<0.05)$. On the other hand, supplementation of the soybean oil diet with $2.5 \mathrm{~g} / \mathrm{kg}$ of CLA produced a reduction in the serum cholesterol of male broilers when compared to the canola oil fed birds $(\mathrm{P}<0.05)$.

There was an effect of the oil source on the total lipid content of giblets $(P<0.05)$. Birds fed soybean oil had a higher $(P<0.05)$ fat liver content $(1.72 \mathrm{~g} / 100 \mathrm{~g})$ than birds receiving canola oil $(1.38 \mathrm{~g} / 100 \mathrm{~g})$. These results 
Zanini et al:: Effect of CLA association with two vegetable oil

Table 2: Final body weight of broilers fed diets supplemented with soybean or canola oil and CLA levels ${ }^{2}$

\begin{tabular}{|c|c|c|c|}
\hline \multirow[b]{2}{*}{$\mathrm{CLA}(\mathrm{g} / \mathrm{kg})$} & \multicolumn{3}{|c|}{ Final body weight $(\mathrm{g})$} \\
\hline & $\begin{array}{l}\text { Soybean } \\
\text { oil }\end{array}$ & $\begin{array}{l}\text { Canola } \\
\text { oil }\end{array}$ & $\bar{x} \mathrm{CLA}$ \\
\hline & \multicolumn{3}{|c|}{ - } \\
\hline 0.0 & 2248 & 2637 & 2442 \\
\hline 2.5 & 2200 & 2640 & 2429 \\
\hline 5 & 2284 & 2635 & 2460 \\
\hline 7.5 & 2404 & 2677 & 2540 \\
\hline 10.0 & 2435 & 2586 & 2510 \\
\hline Oil source & $2314^{b}$ & $2635^{a}$ & \\
\hline SEM & & 55.9 & \\
\hline \multicolumn{4}{|l|}{ Probabilities } \\
\hline CLA & & 0.190 & \\
\hline Oil & & 0.000 & \\
\hline \multirow[t]{2}{*}{ CLA x Oil } & & 0.098 & \\
\hline & \multicolumn{3}{|c|}{ - Females } \\
\hline 0.0 & 2055 & 2263 & $2159^{1}$ \\
\hline 2.5 & 1997 & 2163 & 2080 \\
\hline 5 & 2148 & 2246 & 2197 \\
\hline 7.5 & 2146 & 2341 & 2244 \\
\hline 10.0 & 2116 & 2276 & 2196 \\
\hline Oil source & $2093^{b}$ & $2258^{a}$ & \\
\hline SEM & & 43.2 & \\
\hline \multicolumn{4}{|l|}{ Probabilities } \\
\hline CLA & & 0.005 & \\
\hline Oil & & 0.000 & \\
\hline CLA $\times$ Oil & & ns & \\
\hline
\end{tabular}

${ }_{a, b}$ Averages values within the same row with no common superscript differ by the SNK test $(P<0.05)$. ${ }^{1}$ Linear effect $\left(P<0.05, Y=2127+982 x, R^{2}=0.38\right) .{ }^{2}$ Each value represents mean of eight replicates per treatment with one bird per repetition

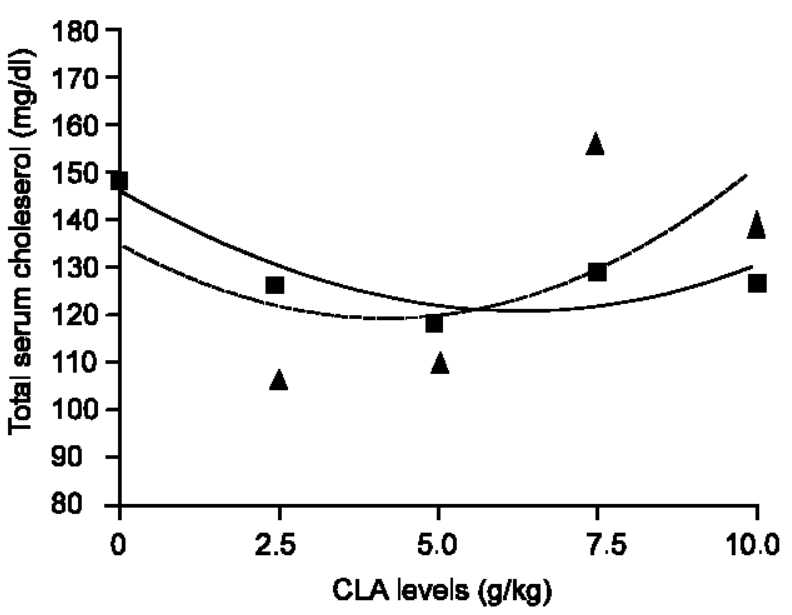

Fig. 2: Total serum cholesterol $(\mathrm{mg} / \mathrm{dl})$ of male broilers fed diets with soybean oil (dashed line, $\mathbf{\wedge}-\mathrm{Y}=$ $134.08-75.81 x+92.97 x^{2}, R^{2}=0.40$ ) or canola oil (continuous line, $\mathbf{\square}-Y=146.47-83.20 \mathrm{x}+$ $67.80 x^{2}, R^{2}=0.78$ ) and supplemented with CLA. Each value is expressed as mean $(n=5 /$ treatment $)$ confirm the observation of heavier $(P<0.05)$ livers $(1.92$ $\mathrm{g} / 100 \mathrm{~g})$ for birds receiving soybean oil in comparison with those of canola oil fed birds $(1.68 \mathrm{~g} / 100 \mathrm{~g})$. Contrary to what was observed with fat liver content, birds receiving canola oil had higher $(P<0.05)$ heart fat content $(11.03 \mathrm{~g} / 100 \mathrm{~g})$ than those receiving soybean oil $(9.21$ $\mathrm{g} / 100 \mathrm{~g})$

An interaction between oil source and CLA levels was also observed on the total lipid content of heart, liver and gizzard $(P<0.05)$. The use of soybean oil and increasing $C L A$ levels resulted in a linear increase $(P<0.05)$ of total lipid on the liver $\left(Y=1.03+1.36 x, R^{2}=0.66\right.$, Fig. 4) and on the gizzard $\left(Y=4.52+0.98 x, R^{2}=0.89\right.$, Fig. 5). The opposite was observed when canola oil was used with CLA since there was a linear decrease $(P<0.05)$ in the total lipid content of gizzard $\left(Y=6.48-1.93 x, R^{2}=0.36\right.$, Fig. 5). Without CLA supplementation gizzard fat content was higher $(P<0.05)$ for birds fed canola oil $(6.23 \mathrm{~g} / 100$ $\mathrm{g}$ ) in comparison to that of birds fed soybean oil (4.48 $\mathrm{g} / 100 \mathrm{~g})$. However, after $5.0 \mathrm{~g} / \mathrm{kg}$ of CLA supplementation this difference did not show up anymore between oil sources (Fig. 5). For birds fed canola oil with CLA, the liver fat content was explained by a quadratic response $\left(Y=1.70-2.18 x+2.07 x^{2}, R^{2}=\right.$ 0.26 , Fig. 4). The lowest fat liver content $(0.81 \mathrm{~g} / 100 \mathrm{~g})$ was observed for birds fed canola oil supplemented with $7.5 \mathrm{~g} / \mathrm{kg}$ of $C L A$ differing $(P<0.05)$ from that of livers of chickens fed soybean oil $(2.18 \mathrm{~g} / 100 \mathrm{~g})$. This same effect was observed with the total serum cholesterol content of males (129.6 and $156.8 \mathrm{mg} / \mathrm{dL}$ ) and females (99.6 and $157.8 \mathrm{mg} / \mathrm{dL}$ ) for birds fed canola and soybean oil, respectively.

The use of CLA with both oils resulted in a quadratic effect $(P<0.05)$ for the heart fat content (Fig. 6). Heart fat content $7.57 \mathrm{~g}$ was lower $(\mathrm{P}<0.05)$ for birds fed soybean oil with $2.5 \mathrm{~g} / \mathrm{kg}$ CLA in comparison with $13.25 \mathrm{~g}$ of heart fat content of birds fed canola oil with $2.5 \mathrm{~g} / \mathrm{kg} \mathrm{CLA} \mathrm{(Fig.}$ $6)$. However, as occur in the liver, there was a lower $(P<0.05)$ heart fat content $(8.78 \mathrm{~g} / 100 \mathrm{~g})$ for birds receiving canola oil with $7.5 \mathrm{~g} / \mathrm{kg}$ CLA in comparison with those receiving soybean oil with $7.5 \mathrm{~g} / \mathrm{kg} \mathrm{CLA} \mathrm{(10.61}$ $\mathrm{g} / 100 \mathrm{~g})$.

\section{Discussion}

The primary objective of the present trial was to evaluate if dietary CLA supplementation in association with an oil source had any important effects on body fat and growth parameters in broilers. In a recent study, it was observed that the use of CLA in association with oils rich in $\omega 3$ fatty acids or in diets that have a balanced ratio of $\omega 6: \omega 3$ has optimized the CLA effect (Aydin et al., 2001) showing that the CLA effect depend upon the oil source in the diet.

The results of the present study demonstrated that the beneficial effects of CLA on body fat in broilers depend of oil source as demonstrated by linear reduction of lipid 
Zanini et al.: Effect of CLA association with two vegetable oil

Table 3: Relative liver weight of broilers fed diets supplemented with soybean or canola oil and CLA levels ${ }^{2}$

\begin{tabular}{|c|c|c|c|}
\hline \multirow[b]{2}{*}{ CLA $(\mathrm{g} / \mathrm{kg})$} & \multicolumn{3}{|c|}{ Liver $(\mathrm{g} / 100 \mathrm{~g})$} \\
\hline & $\begin{array}{l}\text { Soybean } \\
\text { Oil }\end{array}$ & $\begin{array}{l}\text { Canola } \\
\text { Oil }\end{array}$ & $\bar{x} C L A$ \\
\hline & \multicolumn{3}{|c|}{ 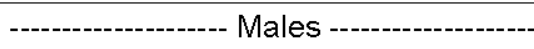 } \\
\hline 0.0 & 1.87 & 1.66 & 1.76 \\
\hline 2.5 & 1.89 & 1.57 & 1.73 \\
\hline 5 & 2.00 & 1.71 & 1.85 \\
\hline 7.5 & 1.91 & 1.81 & 1.86 \\
\hline 10.0 & 1.93 & 1.68 & 1.81 \\
\hline Oil source & $1.92^{\mathrm{a}}$ & $1.68^{\mathrm{b}}$ & \\
\hline SEM & & 0.067 & \\
\hline \multicolumn{4}{|l|}{ Probabilities } \\
\hline CLA & & 0.230 & \\
\hline Oil & & 0.000 & \\
\hline \multirow[t]{2}{*}{$\bar{x}$ CLA $x$ Oil } & & ns & \\
\hline & \multicolumn{3}{|c|}{ 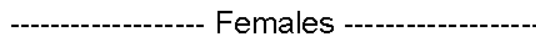 } \\
\hline 0.0 & $1.79^{\mathrm{a}}$ & $1.86^{\mathrm{a}}$ & 1.82 \\
\hline 2.5 & $1.93^{\mathrm{a}}$ & $1.61^{\mathrm{b}}$ & 1.77 \\
\hline 5 & $1.90^{\mathrm{a}}$ & $1.73^{\mathrm{b}}$ & 1.82 \\
\hline 7.5 & $1.95^{\mathrm{a}}$ & $1.80^{b}$ & 1.87 \\
\hline 10.0 & $1.90^{\mathrm{a}}$ & $1.74^{b}$ & 1.82 \\
\hline Oil source & $1.89^{\mathrm{a}}$ & $1.75^{\mathrm{b}}$ & \\
\hline SEM & & 0.059 & \\
\hline \multicolumn{4}{|l|}{ Probabilities } \\
\hline CLA & & ns & \\
\hline Oil & & 0.000 & \\
\hline CLA $x$ Oil & & 0.033 & \\
\hline
\end{tabular}

${ }_{a, b}$ Averages values within the same row with no common superscript differ by the SNK test $(P<0.05)$

${ }^{1}$ Significant effect $(P<0.05)$

${ }^{2}$ Each value represents mean of five (5) replicates per treatment with one bird per repetition

deposition in abdominal fat pad when canola oil was used with CLA but, this effect was not demonstrated when soybean oil was added. Additionally, a linear decrease in the total lipid content of gizzard and a reduction on the relative liver weight in females supplied with CLA and canola oil was also observed. The contrary was observed when soybean oil and CLA were used since there was a linear increase in the total lipid content of liver and gizzard. Brown et al. (2001) have also shown that the CLA effect can be modified by the oil supplement, therefore, these results show that the association of CLA with an other fat should be considered.

Our results showed that the effect of CLA in association with canola oil in lipid deposition was observed only in females that normally have higher lipid deposition compared to males. Corino et al. (2002) observed a lower activity of the enzymes acetyl-CoA carboxylase, glucose-6-phosphate dehydrogenase in females as compared to males.

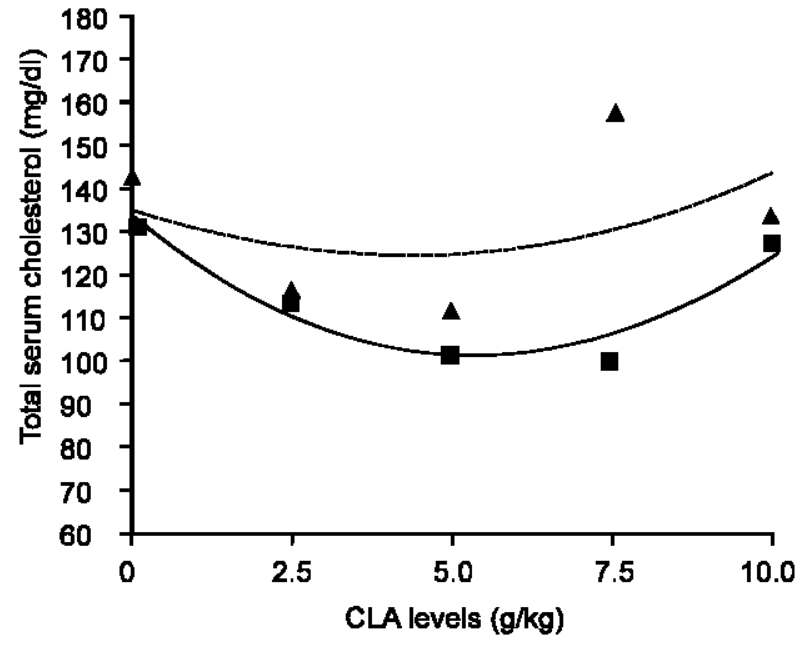

Fig. 3: Total serum cholesterol $(\mathrm{mg} / \mathrm{dl})$ of female broilers fed diets with soybean oil (dashed line, A $-Y=134.918-52.8065 x+61.9926 x^{2}, R^{2}=$ 0.26 ) or canola oil (continuous line, $\mathbf{\square}-Y=$ $\left.134.558-126.159 x+116.365 x^{2}, R^{2}=0.91\right)$ and supplemented with CLA. Each value is expressed as mean ( $n=5 /$ treatment)

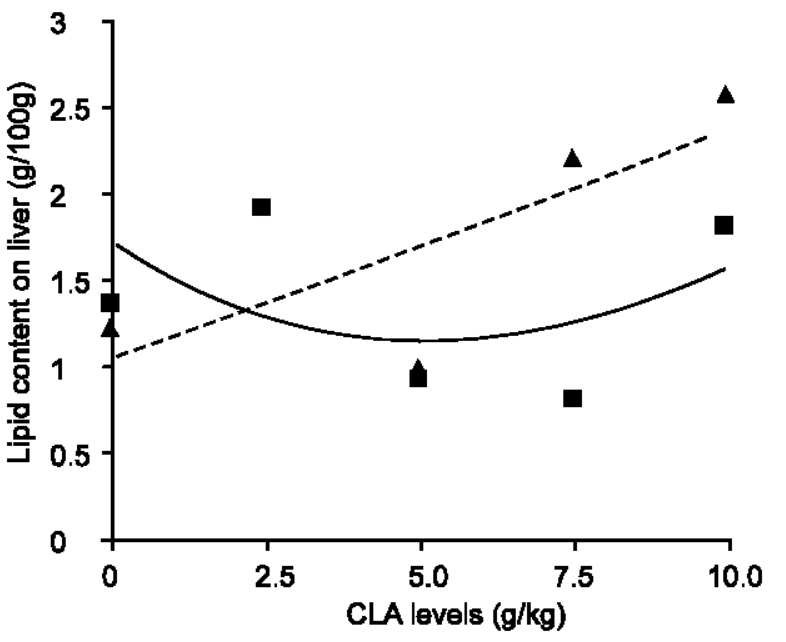

Fig. 4: Total lipid content of liver $(\mathrm{g} / 100 \mathrm{~g})$ of broilers fed diets with soybean oil (dashed line, A $Y=1.03980+1.36733 x, R^{2}=0.66$ ) or canola oil (continuous line, $\mathbf{\square}-Y=1.704-2.183 x+2.070 x^{2}$, $\left.\mathrm{R}^{2}=0.26\right)$ and supplemented with CLA. Each value is expressed as mean ( $n=10 /$ treatment)

Further studies have suggested that CLA may enhance growth. According to previous studies (Ostrowska et al., 1999), the CLA treatment improved the feed utilization over that of the sunflower oil. Thiel-Cooper et al. (2001) verified a linear increase in average daily gain as the level of CLA increased in the diet. Our results showed an 
Zanini et al.: Effect of CLA association with two vegetable oil

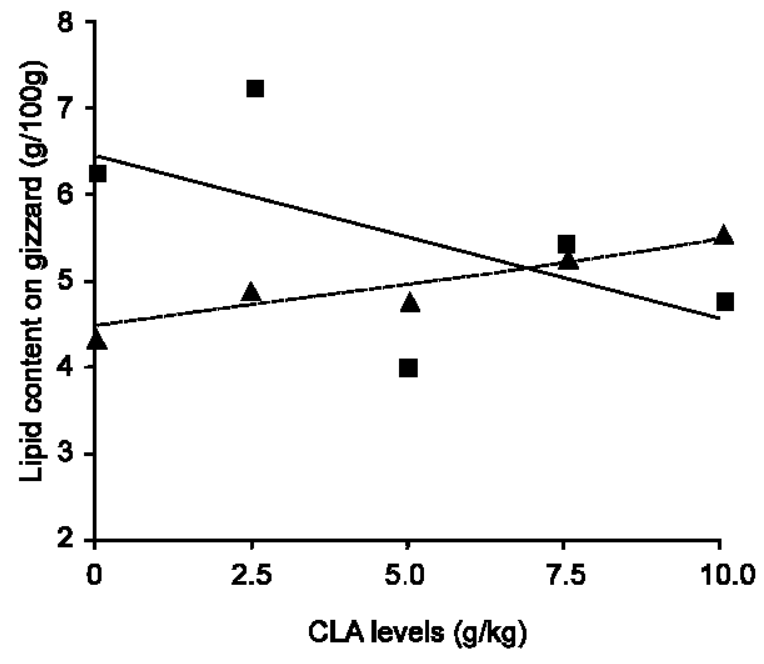

Fig. 5: Total lipid content on gizzard $(\mathrm{g} / 100 \mathrm{~g})$ of broilers fed diets with soybean oil (dashed line, A $Y=4.52819+0.983413 x, R^{2}=0.89$ ) or canola oil (continuos line, $\mathbf{\square}-Y=6.48946-1.93347 x, R^{2}=$ 0.36 ) and supplemented with CLA. Each value is expressed as mean ( $n=10 /$ treatment)

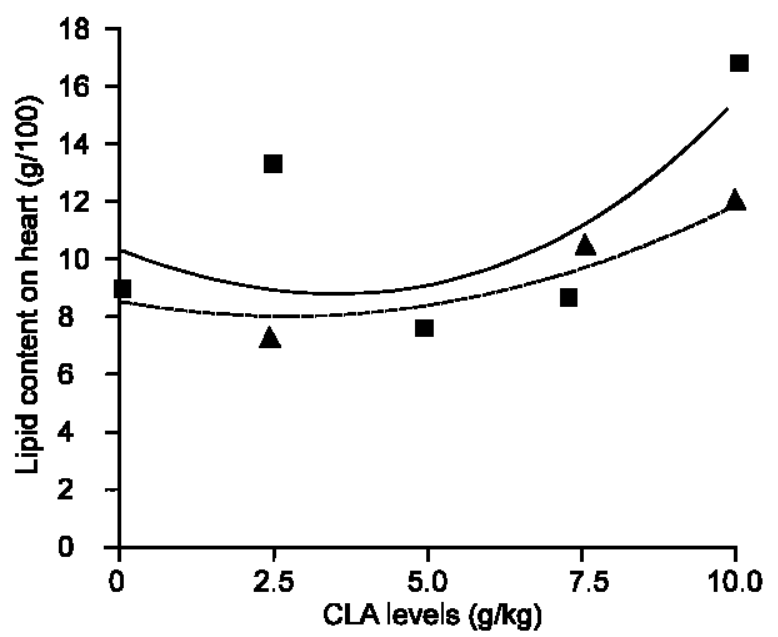

Fig. 6: Total lipid content on heart $(\mathrm{g} / 100 \mathrm{~g})$ of broilers fed diets with soybean oil (dashed line, $\Delta$ $Y=8.43577-4.44579 x+7.99688 x^{2}, R^{2}=0.87$ ) or canola oil (continuous line, $\mathbf{\square}-Y=10.5499$ $\left.10.6712 x+15.5089 x^{2}, R^{2}=0.45\right)$ and supplemented with CLA. Each value is expressed as mean ( $n=10 /$ treatment)

increase in the final body weight of females when supplied CLA.

In the present trial, it was demonstrated that the addition of canola oil resulted in an increase of body weight as well as in a reduction of relative liver weight, in the total serum cholesterol of females birds and in the total liver fat content when compared with soybean oil. Fatty acid production in birds occur mainly in the liver, therefore the lighter livers of male and female birds fed canola oil found in this study was probably due to a reduction in the endogenous production of lipids as also shown by the reduced serum cholesterol levels in the females. Thus, both CLA and canola oil, associated or not, can affect body fat by decreasing synthesis and increasing oxidation.

\section{Conclusions}

1. Canola oil fed birds were heavier than soybean oil fed birds.

2. Relative liver weight in both sexes and serum cholesterol in the females were reduced by the canola oil diet.

3. The CLA response on abdominal fat deposition depends upon sex and the source of fat added to the diet.

4. The effect of CLA in reducing total serum cholesterol, liver weight and total lipid content of giblets was dependent on oil source.

\section{Acknowledgments}

The authors are grateful to the National Research Council (CNPq) for financial support and to the BASF Animal Nutrition and Bunge Foods S.A. for technical support.

\section{References}

Akahoshi, A., K. Koba, S. Ohkura-Kaku, N. Kaneda, C. Goto, H. Sano, T. Iwata, Y. Yamauchi, K. Tsutsumi and M. Sugano, 2003. Metabolic effects of dietary conjugated linoleic acid (CLA) isomers in rats. Nutr. Res., 23: 1691-1701.

Aydin, R., M.W. Pariza and M.E. Cook, 2001. Olive oil prevents the adverse effects of dietary conjugated linoleic acid on chick hatchability and egg quality. J. Nutr., 131: 800-806.

Banzatto, D.A. and S.N. Kronka, 1992. Experimentação agrícola. FUNEP, Jaboticabal.

Bauman, D., 2001. Update on conjugated linoleic acids (CLA). Cornell Nutrition Conference. Proceedings. October. 16-18, Ithaca, NY.

Brown, M., M. Evans and M. Mcintosh, 2001. Linoleic acid partially restores the triglyceride content of conjugated linoleic acid-treated cultures of 3T3-L1 preadipocytes. J. Nutr. Biochem., 12: 381-387.

Clark, S.D., 1993. Regulation of fatty acid synthase gene expression: an approch for reducing fat accumulation. J. Anim. Sci., 71: 1957-1965.

Corino, C., J. Mourot, S. Magni, G. Pastorelli and F. Rosi, 2002. Influence of dietary conjugated linoleic acido on growth, meat qualit, lipogenesis, plasma leptin and physiological variables of lipid metabolism in rabbits. J. Anim. Sci., 80: 1020-1028. 
Zanini et al.: Effect of CLA association with two vegetable oil

Folch, J., M. Lees and G.H. Sloane-Stanley, 1957. A simple method for the isolation and purification of total lipids from animal tissues. J. Biol. Chem., 226: 497-509.

Ostrowska, E., M. Muralitharan, R.F. Cross, D.E. Bauman and F.R. Dunshea, 1999. Dietary conjugated linoleic acids increase lean tissue and decrease fat deposition in growing pigs. J. Nutr., 129: 2037-2042.

Pariza, M., Y. Park, S. Kim, K. Sugimoto, K. Albright, W. Liu, J. Storkson and M. Cook, 1997. Mechanism of body fat reduction by conjugated linoleic acid. FASEB J., 11: A139.

Park, Y., K. Albright, W. Liu, J. Storkson, M. Cook and M. Pariza, 1999. Changes in body composition in mice during feeding and withdrawal of conjugated linoleic acid. Lipids, 34: 243-248.
Thiel-Cooper, R.L., F.C. Parrish, J.C. Sparks-Jr, B.R. Wiegand and R.C. Ewan, 2001. Conjugated linoleic acid changes swine performance and carcass composition. J. Anim. Sci., 79: 1821-1828.

Universidade Federal de Viçosa - UFV, 1997. Manual de utilização do programa SAEG (Sistema para Análise Estatística e Genéticas). UFV, Viçosa.

Wiegand, B.R., J.C. Sparks-Jr., F.C. Parrish and D.R. Zimmerman, 2002. Duration of feeding conjugated linoleic acid influences growth performance, carcass traits, and meat quality of finishing barrows, J. Anim. Sci., 80: 637-643. 